\title{
Analisis Kesalahan Fonologis Membaca Teks Bahasa Arab Siswa Madrasah Tsanawiyah Lampung Selatan
}

\author{
Muhammad Afif Amrulloh \\ Universitas Islam Negeri (UIN) Raden Intan Lampung \\ afif.amrulloh@radenintan.ac.id \\ Haliyatul Hasanah \\ haliyatulhasanah@gmail.com \\ Universitas Islam Negeri (UIN) Raden Intan Lampung
}

\begin{abstract}
This study aims to find and reduce the location of errors in learning Arabic in the aspect of reciting Arabic letters (makhorijul letters) with the error analysis method. Focus more specifically on the phonetic aspect, namely on letters that sound like sounds. In addition, this study also aims to determine the forms of errors in reading Arabic texts in the phonological level (phonetic / makhroj aspects). This type of research is a qualitative study, conducted at MTs. Raudlatul Jannah Natar, South Lampung. Understanding the study of how to pronounce or sound Arabic letters is very important in learning Arabic to avoid pronunciation errors, so it does not hamper the learning process. The results of this study indicate that the forms of phonological errors that often occur when reading Arabic text activities are errors in sound in terms of articulation factors including among them: 1) apico-dental-alveolar sound. 2) Inter-dental sound. 3) Foronto-palatal sounds. 4) Dorsouvular sound. 5) Dorso-velar sound. 6) Sound of avico-alveolars. 7) The sound of root-pharyngeals. The sound error in terms of aspects of articulation that is in: 1) fricative sound. 2) pop sound.
\end{abstract}

Keywords: Reading errors, phonology, Arabic language

\begin{abstract}
Abstrak
Penelitian ini bertujuan mencari dan mengurangi letak kesalahan dalam mempelajari bahasa Arab pada aspek pelafalan huruf-huruf Arab (makhorijul huruf) dengan metode analisis kesalahan. Lebih khusus berfokus pada aspek fonetik yaitu pada huruf-huruf yang terdengar mirip bunyinya. Selain itu, penelitian ini juga bertujuan untuk mengetahui bentuk-bentuk kesalahan dalam membaca teks berbahasa Arab dalam tataran fonologi (aspek fonetik/makhroj).
\end{abstract}


Jenis penelitian ini adalah penelitian kualitatif, yang dilakukan di MTs. Raudlatul Jannah Natar Lampung Selatan. Pemahaman terhadap kajian cara pelafalan atau pembunyian huruf Arab sangat penting dalam pembelajaran bahasa Arab untuk menghindari terjadi kesalahan pelafalan, sehingga tidak menghambat proses pembelajaran. Hasil penelitian ini menunjukkan bahwa bentukbentuk kesalahan fonologi yang sering terjadi pada saat kegiatan membaca teks berbahasa Arab yaitu kesalahan pada bunyi yang ditinjau dari aspek faktor artikulasinya diantaranya ada pada: 1) bunyi apico-dental-alveolar. 2) Bunyi inter-dental. 3) Bunyi forontopalatal. 4) Bunyi dorso-uvular. 5) Bunyi dorso-velar. 6) Bunyi avicoalveolars. 7) Bunyi root-pharyngeals. Adapun kesalahan bunyi yang ditinjau dari aspek cara artikulasinya yaitu ada pada: 1) bunyi frikatif. 2) bunyi letupan.

Kata Kunci: Kesalahan membaca, fonologi, bahasa Arab

\section{Pendahuluan}

Analisis kesalahan merupakan subuah proses yang didasarkan pada analisis kesalahan orang yang sedang belajar dengan objek yang jelas. Jelas yang dimaksudkan yaitu sesuatu yang telah ditargetkan berupa bahasa ${ }^{1}$. Menurut Ellis (ahli pengajaran bahasa) mengemukakan bahwa analisis kesalahan memiliki lima langkah kerja yang meliputi: pengumpulan sampel kesalahan, pengidentifikasian kesalahan, penjelasan kesalahan, pengklasifikasian kesalahan (berdasarkan penyebabnya), dan pengevaluasian kesalahan.Kesalahan fonologi atau kesalahan pengucapan merupakan kesalahan dalam mengucapkan kata sehingga menyimpang dari ucapan baku atau bahkan menimbulkan perbedaan makna. Dari term ini dapat dipahami, bahwa kesalahan berbahasa dari segi fonologi merupakan kesalahan berbahasa yang terjadi karena kesalahan pelafalan bunyi bahasa yang dihasilkan oleh alat ucap manusia sehingga dapat terjadi perbedaan makna. Adanya kesalahan dalam pembelajaran bahasa bukanlah hal yang aneh, karena kesalahan adalah bagian dari proses belajar yang tidak terhindarkan. Namun, para pakar linguistik dan para guru bahasa sependapat bahwa kesalahan berbahasa itu dapat mengganggu tercapainya tujuan pengajaran bahasa.

Maka demi kelancaran dan kebaikan dalam pelafalan bacaan Arab, setiap huruf harus harus dibunyikan sesuai artikulasinya. Kesalahan dalam artikulasi dapat menimbulkan perbedaan makna atau kesalahan arti pada bacaan yang sedang dibaca. Dalam kondisi tertentu, kesalahan ini bahkan dapat menyebabkan kekafiran apabila dilakukan dengan sengaja. Untuk itu kebenaran dalam melafalkan bacaan Arab (huruf hijaiyyah) sangatlah penting. Hal ini

${ }^{1}$ Suprianti, “Analisis Kesalahan Pelafalan Bunyi Bahasa Prancis Siswa Kelas XI SMA Negeri 2 Sleman.” 
dilakukan sebagai bentuk aturan yang harus ditatati oleh setiap penutur bahasa tertentu. Penutur asli yang menuturkan bahasa tersebut melakukan tuturan ssesuai artikulasinya. Hal ini penting untuk kelanjutan eksistensi suatu bahasa sehingga jika tidak ada lagi penutur yang baik, maka punahlah bahasa tersebut. Tidak ada bahasa yang eksis di dunia tanpa ada penutur ${ }^{2}$.

Dari konteks ini, apabila kita dapat menguasai artikulasi dengan baik dan benar, maka kita tidak akan mengalami kesalahan-kesalahan yang mungkin terjadi pada saat melafalkan bacaan Arab. Karena sejatinya esensi dari berbahasa adalah untuk menghasilkan rangkaian sejumlah kata dalam kalimat yang bermakna dan sesuai dengan kaidah yang ada, tidak terjadi kesalahan di dalamnya. ${ }^{3}$ Adapun kesalahan-kesalahan tersebut terjadi pada Siswa kelas VII A MTs. Raudlatul Jannah Natar. MTs. Raudlatul jannah merupakan salah satu lembaga pendidikan Islam berbasis Pondok Pesantren, yang mana lembaga Pendidikan ini dikelola oleh Yayasan SWADHIPA yang letaknya di desa Bumi Sari, Natar.

Bahkan menurut M.Tontowi bahwa saat ini banyak guru bahasa Arab yang tidak mampu berbicara atau melafalkan huruf Arab sesuai dengan fonemik Arab. Ketika diperdengarkan ke orang Arab, mereka tidak maengerti apa yang dimaksud sehingga terjadi kegagalan makna atau kesalahpahaman. Dengan demikian pengetahuan tentang bahasa tidak hanya seputar morfem saja namun juga harus menguasai bunyi bahasa atau fonologi. ${ }^{4}$

Dengan demikian, mengenai permasalahan di atas juga terdapat penelitian serupa yang terkait dengan analisis kesalahan fonologi ini yang pernah dilakukan sebelumnya oleh Batmang, penelitian dengan judul "Kesalahan Fonologi dalam Berbicara Bahasa Arab Pada Mahasiswa Matrikulasi STAIN Kendari". Menunjukkan bahwa kesalahan fonologis diakibatkan oleh keterbatasan responden dalam memproduksi ujaran dan masih terpengaruh oleh bahasa pertama ${ }^{5}$.

Fitria Lathifah, Syihabuddin, dan M. Zaka Al Farisi, penelitian dengan judul "Analisis Kesalaban Fonologis Dalam Keterampilan Membaca Teks Babasa Arab". Menunjukkan bahwa kesalahan fonologis yang sering terjadi saat membaca yaitu pada suara frikatif dan suara letupan ${ }^{6}$. Penelitian Nurjannah Lubis., penelitian

\footnotetext{
${ }^{2}$ Amrulloh, "Kesamaan Bunyi Pada Sajak (Kajian Fonologi Al-Qur’an Dalam Surat Al 'Asar)."

${ }^{3}$ Mufarodi, "Fonologi Dan Morfologi Bahasa Arab 'Âmiyah Mesir."

4 M.Tontowi, "Fonologi Dalam Pendidikan dan Pelatihan Bahasa Arab Guru Mi Tingkat Dasar Pada Diklat Keagamaan Kota Palembang."

5 Batmang, "Kesalahan Fonologis Dalam Berbicara Bahasa Arab Pada Mahasiswa Matrikulasi Stain Kendari."

${ }^{6}$ Fitria Lathifah, Syihabuddin Syihabuddin, "Analisis Kesalahan Fonologis Dalam Keterampilan Membaca Teks Bahasa Arab.”
} 


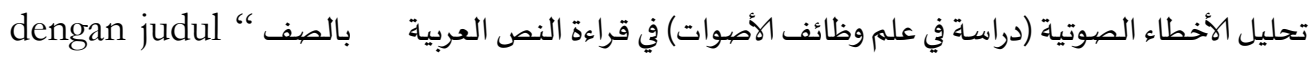

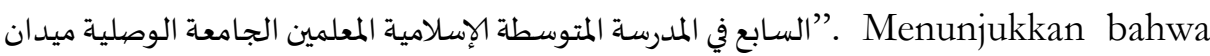
kesalahan berbahasa dalam membaca teks bahasa Arab siswa kelas VII MTs Muallimin UNIVA Medan karena salah satunya yaitu kurangnya kemampuan guru dalam melafalkan bahasa Arab dengan baik ${ }^{7}$

Berdasarkan hasil observasi dan wawancara dengan guru bahasa Arab di MTs. Raudlatul Jannah, yang mengungkapkan bahwa pada saat proses pembelajaran bahasa Arab berlangsung khususnya Maharatul Qiro'ah (membaca teks bahasa Arab), para siswa belum mampu membedakan dan melafalkan bunyi huruf hijaiyyah (pelafalan fonetik arab) dengan baik dan benar, bahkan sebagian siswa ada yang menganggap bacaan teks Arab sama seperti Bacaan Al-qur'an, sehingga cara membacanya pun seperti membaca Al-qur'an yang menggunakan hukum tajwid. Hal ini, menimbulkan Kesalahan fonologi yang terjadi pada siswa kelas VII A MTs. Raudlatul Jannah Natar pada saat proses pembelajaran bahasa Arab. Adapun Beberapa kesalahan fonologi yang banyak dijumpai dalam membaca teks bahasa Arab, diantaranya kesalahan dalam melafalkan huruf ص dan huruf $\varepsilon \cdot{ }^{8}$

Penelitian ini bertujuan mencari dan mengurangi letak kesalahan dalam mempelajari bahasa Arab pada aspek pelafalan huruf-huruf Arab (makhorijul huruf) dengan metode analisis kesalahan. Lebih khusus berfokus pada aspek fonetik yaitu pada huruf-huruf yang terdengar mirip bunyinya. Selain itu, penelitian ini juga bertujuan untuk mengetahui bentuk-bentuk kesalahan dalam membaca teks berbahasa Arab dalam tataran fonologi (aspek fonetik/makhroj). Jenis penelitian ini adalah penelitian kualitatif, yang dilakukan di MTs. Raudlatul Jannah Natar Lampung Selatan.

\section{Hasil dan Pembahasan}

Bahasa Arab mempunyai jenis vokal panjang dan penggandaan konsonan yang tidak dimiliki oleh bahasa lain seperti bahasa Indonesia. Bahkan bunyi-bunyi yang berdekatan dan bunyi emfatik adalah ciri khas yang dimiliki bahasa Arab yang kerap kali menjadi problem bagi pembelajaran bahasa. Profil fonologi bahasa Arab mengandung 28 konsonan, tiga vokal pendek dan tiga vokal panjang. Bahasa Arab pun juga memiliki diftong /ay/ dan /aw/. ${ }^{9}$ Dengan demikian, pertemua dua kebudayaan, yaitu bahasa Indonesia dan bahasa Arab

7 Lubis, Nur Janah. "Tahlil al-Akhtha' al-Shauthiyah (Dirasah Fi Ilm Wazhaif alAshwat) Fi Qira'ah al-Nash al-'Arabiyah Bi al-Shaf al-Sabi’ Fi al-Madrasah al-Mutawasithah alIslamiyah al-Mu'allimin al-Jami’ah al-Washliyah Medan.” UIN Sumatera Utara, 2018..”

8 Hasil Observasi dan Wawancara Dengan Guru Bahasa Arab Kelas VII A MTs. Raudlatul Jannah Natar, 19 Maret 2018.

${ }^{9}$ Eric Kunto Aribowo, "Fonologi Dan Ortogtrafi Bahasa Arab." 
yang berujung pada interaksi antar dua bahasa sering kali terjadi dan menimbulkan perubahan bahasa. ${ }^{10}$ Bahkan tidak hanya itu, sering memunculkan kesalahan berbahasa, khususnya pada aspek fonologi. Dengan demikian, untuk mengurangi terjadinya kesalahan berbahasa, yaitu pada aspek kesalahan pelafalan bunyi-bunyi bahasa Arab dibutuhkan kemampuan yang mapan terhadap penguasaan bahasa Arab. Kesalahan yang terjadi dalam pelafalan bahasa Arab mengakibatkan kesalahan berikutnya pada aspek lain, seperti penulisan sampai pada kesalahan menangkap maksud yang diinginkan. ${ }^{11}$

Dalam penelitian ini, peneliti menemukan banyak kesalahan dalam artikulasi (makhorijul huruf) yang terjadi pada siswa kelas VII A MTs. Raudlatul Jannah Natar saat membaca teks berbahasa Arab. Oleh sebab itu banyak kata

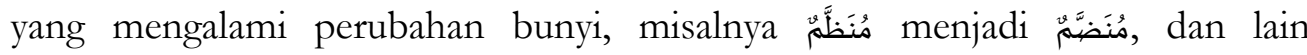
sebagainya. Adapun hasil analisis sebagai berikut : 1) Huruf شenjadi ش Huruf

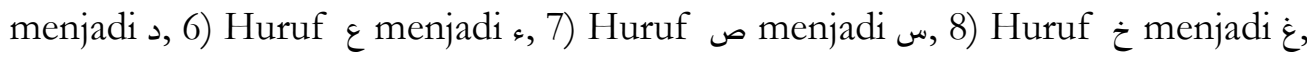
9) Huruf $\dot{\tau}$ menjadi s,10) Huruf $\dot{\varepsilon}$ menjadi $\dot{\tau}$, 11) Huruf $\varepsilon$ menjadi $\dot{\varepsilon}, 12)$ Huruf $\dot{\varepsilon}$ menjadi o, 13) Huruf $\tau$ menjadi $\dot{\tau}$, 14) Huruf b menjadi $ض, 15)$ Huruf ص menjadi ض, 16) Huruf $\varepsilon$ menjadi ه , 17) Huruf b menjadi ت, ط Huruf ذ menjadi j, 19) Hurufj menjadi ج, 20) Huruf s menjadi ق ق ص

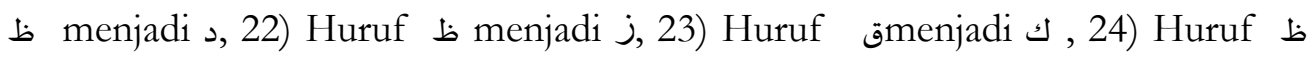
menjadi ج, 25) Huruf ظenjadi ذ, 26) huruf b menjadi ${ }^{12}$

\section{Identifikasi Kesalahan}

Daftar kesalahan fonologi (aspek fonetik/makhroj) pada teks berbahasa Arab Siswa MTs. Raudlatul Jannah

\begin{tabular}{|c|c|c|}
\hline \multicolumn{2}{|c|}{ Ekspresi Siswa } & \multirow{2}{*}{ Deskripsi yang Benar } \\
\cline { 1 - 2 } $\begin{array}{c}\text { Lafal Huruf yang } \\
\text { Salah }\end{array}$ & $\begin{array}{c}\text { Lafal Huruf } \\
\text { yang Benar }\end{array}$ & \\
\hline Membunyikan شيدة، مشجب، & & \\
\hline
\end{tabular}

10 Akhmad Dzukaul Fuad, "Keunikan Fonologi Bahasa Arab Etnis Migran Di Nusantara (Studi Kasus Pada Kampung Arab Pamekasan Madura)."

${ }^{11}$ Mohd Azidan Abdul Jabbar, "Gangguan Bunyi Melayu Dalam Sebutan Arab : Satu Analisis Ringkas."

${ }^{12}$ Hasil Tes Bacaan Teks Berbahasa Arab Siswa Kelas VII A MTs. Raudlatul Jannah, 02 September 2018. 


\begin{tabular}{|c|c|c|}
\hline س dengan & 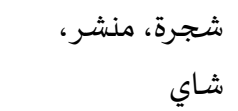 & $\begin{array}{c}\text { artikulasi di tengah lidah dan } \\
\text { dimantapkan dengan langit-langit atas. }\end{array}$ \\
\hline $\begin{array}{c}\text { Membunyikan } \\
\text { dengan }\end{array}$ & كمثرى، ممثل & $\begin{array}{l}\text { Tsa' (ث) : bunyi frikatif, letak artikulasi } \\
\text { di ujung lidah bertemu dengan ujung } \\
\text { gigi depan yang atas. }\end{array}$ \\
\hline ص س Membunyikan & فصلى، قصعنة، صحن، & \multirow[t]{2}{*}{$\begin{array}{c}\text { Shod (ص) : bunyi frikatif, letak } \\
\text { artikulasinya di ujung lidah antara gigi } \\
\text { atas dan bawah (gusi), namun lebih } \\
\text { dekat ke bawah. }\end{array}$} \\
\hline $\begin{array}{c}\text { Membunyikan ص ض dengan } \\
\text { dengn }\end{array}$ & فصل & \\
\hline $\begin{array}{c}\text { Membunyikan ض } \\
\text { dengan د }\end{array}$ & مضرحاض، منضدة، & $\begin{array}{l}\text { Dhod (ض) : bunyi letupan, letak } \\
\text { artikulasinya dibagian sisi lidah } \\
\text { bertemu geraham atas. }\end{array}$ \\
\hline $\begin{array}{c}\text { Membunyikan ذ } \\
\text { dengan j }\end{array}$ & هذا، هذه & \multirow[t]{2}{*}{$\begin{array}{l}\text { Dzal (ذ) : bunyi frikatif, letak } \\
\text { artikulasinya di ujung lidah bertemu } \\
\text { dengan ujung gigi depan yang atas. }\end{array}$} \\
\hline $\begin{array}{c}\text { Membunyikan ذ } \\
\text { dengan د }\end{array}$ & باذنجان & \\
\hline
\end{tabular}




\begin{tabular}{|c|c|c|}
\hline $\begin{array}{l}\text { Membunyikan j } \\
\text { dengan } ج\end{array}$ & مزبل، مزيزة، خزانة، رزّ، & $\begin{array}{c}\text { Zai }(j) \text { : bunyi frikatif, letak } \\
\text { artikulasinya di ujung lidah antara gigi } \\
\text { atas dan bawah (gusi), namun lebih } \\
\text { dekat ke bawah. }\end{array}$ \\
\hline $\begin{array}{c}\text { Membunyikan } \varepsilon \\
\text { dengan }\end{array}$ & 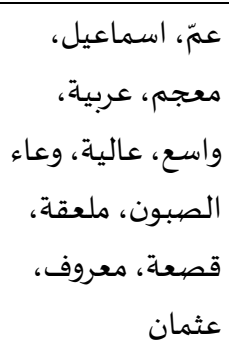 & $\begin{array}{l}\text { 'Ain }(\varepsilon) \text { : bunyi frikatif, letak } \\
\text { artikulasinya di bagian tengah } \\
\text { tenggorokan. }\end{array}$ \\
\hline $\begin{array}{c}\text { Membunyikan } \\
\text { dengan }=\end{array}$ & فاطمة، بطاطس، & $\begin{array}{c}\text { Tho' ( }(\text { ) : bunyi letupan, letak } \\
\text { artikulasinya di bagian ujung lidah } \\
\text { bertemu gusi atas. }\end{array}$ \\
\hline $\begin{array}{c}\text { Membunyikan b } \\
\text { dengan ض }\end{array}$ & مطار & \\
\hline $\begin{array}{c}\text { Membunyikan } \\
\text { dengan }\end{array}$ & منظّم & $\begin{array}{l}\text { Zho’ (ظ) : bunyi frikatif, letak } \\
\text { artikulasinya di ujung lidah bertemu } \\
\text { dengan ujung gigi depan yang atas. }\end{array}$ \\
\hline $\begin{array}{l}\text { Membunyikan b } \\
\text { dengan j }\end{array}$ & نظيف، منظّم، & \\
\hline
\end{tabular}


216 | Arabiyatuna : Jurnal Bahasa Arab, Vol. 3, No. 2, 2019

\begin{tabular}{|c|c|c|}
\hline $\begin{array}{l}\text { Membunyikan } b \\
\text { dengan } ج\end{array}$ & انظر & \\
\hline $\begin{array}{c}\text { Membunyikan b } \\
\text { dengan ذ }\end{array}$ & انظر & \\
\hline $\begin{array}{c}\text { Membunyikan } \\
\text { dengan د }\end{array}$ & منظّم، نظيف & \\
\hline $\begin{array}{c}\text { Membunyikan } \varepsilon \\
\text { dengan } \dot{\varepsilon}\end{array}$ & معروف & $\begin{array}{l}\text { 'Ain }(\varepsilon) \text { : bunyi frikatif, letak } \\
\text { artikulasinya di bagian tengah } \\
\text { tenggorokan. }\end{array}$ \\
\hline $\begin{array}{c}\text { Membunyikan } \\
\text { dengan }\end{array}$ & معجم & \\
\hline $\begin{array}{c}\text { Membunyikan } \dot{\varepsilon} \\
\text { dengan }\end{array}$ & غرفبخ، غطاء، & $\begin{array}{l}\text { Ghoin }(\dot{\xi}) \text { : bunyi frikatif, letak } \\
\text { artikulasinya di bagian ujung } \\
\text { tenggorokan. }\end{array}$ \\
\hline $\begin{array}{l}\text { Membunyikan antara } \\
\dot{\varepsilon} \text { dengan } \dot{z}^{\text {terdengar }} \\
\text { sama dan bacaannya } \\
\text { samar }\end{array}$ & غرفة، غطاء & \\
\hline
\end{tabular}




\begin{tabular}{|c|c|c|}
\hline $\begin{array}{c}\text { Membunyikan } \\
\text { dengan }\end{array}$ & تحاجح، حقيبة، & $\begin{array}{l}\mathrm{Ha}(\tau) \text { : bunyi frikatif, letak } \\
\text { artikulasinya di bagian tengah } \\
\text { tenggorokan. }\end{array}$ \\
\hline $\begin{array}{c}\text { Membunyikan } \tau \\
\text { dengan } \dot{\tau}\end{array}$ & حقيبة & \\
\hline $\begin{array}{c}\text { Membunyikan } \\
\text { dengan }\end{array}$ & خزانة، أختي، مطبخ، & $\begin{array}{l}\text { Kho' }(\dot{\tau}) \text { : bunyi frikatif, letak } \\
\text { artikulasinya di bagian ujung } \\
\text { tenggorokan. }\end{array}$ \\
\hline $\begin{array}{c}\text { Membunyikan } \\
\text { dengan } \dot{\varepsilon}\end{array}$ & مطبخ، مغرفة & \\
\hline $\begin{array}{l}\text { Membunyikan antara } \\
\text { قdengan sterdengar } \\
\text { sama }\end{array}$ & حقيبة & $\begin{array}{l}\text { Qof (ق) : bunyi letupan, letak } \\
\text { artikulasinya di bagian antara panggal } \\
\text { lidah (paling belakang) yang bertemu } \\
\text { dengan anak tekak. }\end{array}$ \\
\hline
\end{tabular}




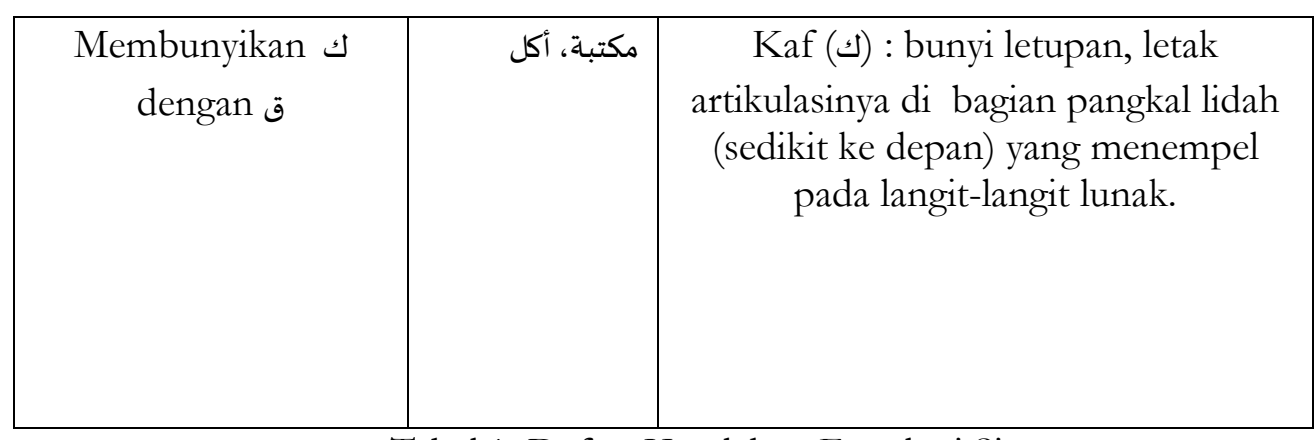

Tabel.1. Daftar Kesalahan Fonologi Siswa

\section{Klasifikasi Kesalahan}

\section{Bunyi Apico-dental-alveolar}

Perubahan bunyi huruf ض menjadi , huruf menjadi dan ض ف terjadi karena adanya proses artikulasi yang sama, sehingga menghasilkan bunyi yang mirip melalui sentuhan ujung lidah kepada pangkal gigi atas depan gusi. Selain itu, proses ini juga menghasilkan beberapa konsonan dalam bahasa Indonesia اض/, /د/, /ط/, /. Hal ini yang menyebabkan para siswa belum bisa membedakan bunyinya dan cara mengartikulasikannya (pelafalannya) sehingga lebih cenderung

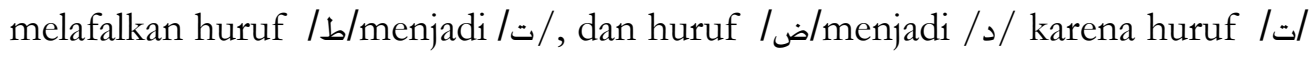

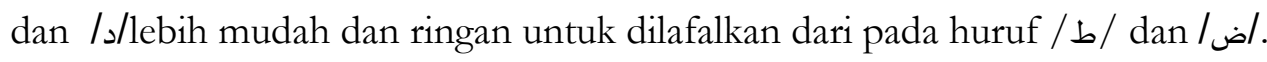

\section{Bunyi Avico-alveolars}

Perubahan bunyi huruf j menjadi ج, dan huruf menjadi w terjadi karena proses artikulasi yang berdekatan seperti bunyi huruf jang dihasilkan melalui sentuhan ujung lidah kepada gusi yang menyebabkan penyempitan keluarnya udara yang kemudian keluar secara pelan-pelan tanpa

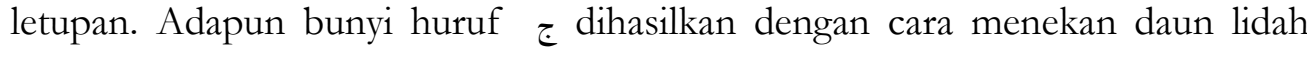
pada langit-langit keras. Hal ini menyebabkan para siswa kesulitan dan belum bisa membedakan bunyi huruf-huruf tersebut pada saat proses artikulasi sehingga lebih cenderung menghasilkan bunyi yang sama/mirip karena huruf

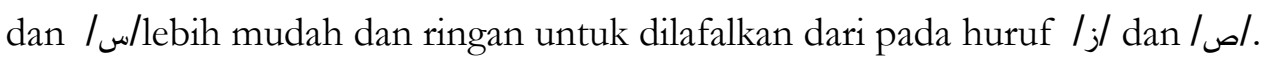

\section{Bunyi Dorso-velar}

Perubahan bunyi huruf كmenjadi ق huruf $\dot{\tau}$ menjadi sdan $\dot{\xi}$, dan huruf $\dot{\xi}$ menjadi $\dot{\tau}$ dan $ه$, terjadi karena proses artikulasi yang berdekatan antara huruf

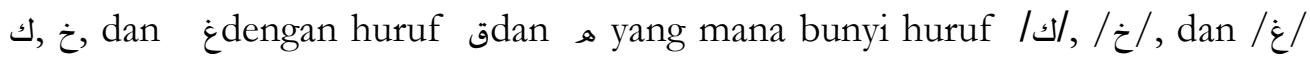
dihasilkan dengan cara menempelkan belakang lidah pada langit-langit lunak. 
Sedangkan bunyi huruf / / dihasilkan melalui pertemuan antara pangkal lidah dengan anak tekak, sehingga udara terhambat secara sempurna. Adapun bunyi huruf sdihasilkan dengan cara merapatkan dua pita suara sehingga rongga paruparu yang melewati antara akar lidah dan dinding belakang rongga kerongkongan terhambat. Namun, beberapa siswa masih belum bisa membedakan bunyi huruf-huruf tersebut. Hal ini menyebabkan para siswa lebih

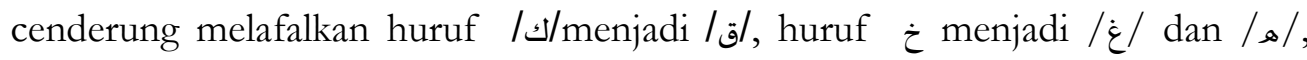
huruf / $/ \dot{\xi} /$ menjadi $/ \dot{\tau} /$ dan / ه/ sehingga bunyi yang dihasilkan sama, karena bunyi huruf / / / hampir mirip dengan bunyi huruf / ketika berbaris sukun dan kasroh, dan huruf $/ \dot{z}$ /hampir mirip dengan bunyi / $/$ / maupun / ه / ketika berbaris sukun dan kasroh, begitu pula dengan huruf $/ \dot{\xi} /$ yang hampir mirip bunyinya dengan bunyi huruf $/ \dot{\tau} /$ dan $/ \& /$ ketika berbaris kasroh, sukun dan fathah.

\section{Bunyi Inter-dental}

Perubahan bunyi huruf $ذ$ menjadi د dan j, huruf $ث$ menjadi

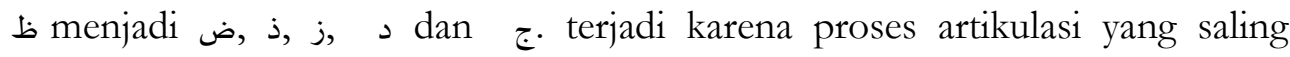

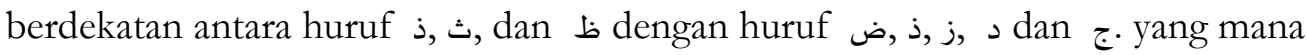
bunyi huruf $\dot{j}$, , dan dihasilkan dengan cara meletakkan ujung lidah antara gigi atas dan bawah tanpa menutup arus udara secara sempurna. Sedangkan bunyi huruf ض dan د dihasilkan melalui sentuhan ujung lidah kepada pangkal gigi atas depan gusi. Selain itu, bunyi huruf $j$ dihasilkan melalui sentuhan ujung lidah kepada gusi yang menyebabkan penyempitan keluarnya udara yang kemudian keluar secara pelan-pelan tanpa letupan. Adapun bunyi huruf ج dihasilkan dengan cara menekankan daun lidah pada langit-langit keras. Namun hal ini menyebabkan para siswa masih belum bisa membedakan bunyi huruf-huruf

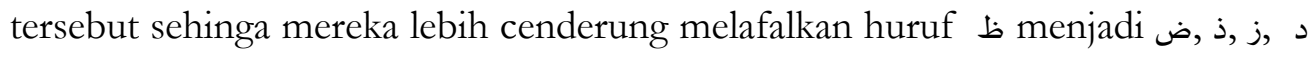
dan , huruf ذ menjadi د dan $j$, kemudian huruf huruf tersebut memiliki bunyi yang hampir sama/mirip sehingga lebih mudah untuk dilafalkan.

\section{Bunyi Foronto-palatal}

Perubahan bunyi huruf ش menjadi w terjadi karena proses artikulasi yang berdekatan antara bunyi huruf ش ش ش lidah pada langit-langit keras, dan bunyi huruf w yang dihasilkan melalui sentuhan ujung lidah kepada gusi yang menyebabkan penyempitan keluarnya udara yang kemudian keluar secara pelan-pelan tanpa letupan. Hal ini menyebabkan para siswa belum bisa membedakan bunyi kedua huruf tersebut 
sehingga mereka lebih cenderung melafalkan huruf ش dengan bunyi huruf س karena kedua huruf tersebut memiliki bentuk dan bunyi yang hampir sama/mirip sehingga lebih mudah untuk dilafalkan.

\section{Bunyi Dorso-uvulars}

Perubahan bunyi huruf $ق$ menjadi sterjadi karena proses artikulasi yang berdekatan antara huruf ق ق dihasilkan melalui pertemuan antara pangkal lidah dengan anak tekak, sehingga udara terhambat secara sempurna. Sedangkan bunyi huruf /S/ dihasilkan dengan cara menempelkan belakang lidah pada langit-langit lunak. Namun, beberpa siswa masih belum bisa membedakan bunyi huruf tersebut. Hal ini menyebabkan para siswa lebih cenderung melafalkan huruf / menggunakan huruf / / sehingga bunyi yang dihasilkan sama, karena huruf / / / lebih ringan dilafalkan dari pada huruf/ق/.

\section{Bunyi Rooto-pharyngeals}

Perubahan bunyi huruf $\tau$ menjadi o dan $\dot{\tau}$, huruf $\varepsilon$ menjadi $\&$, dan غterjadi karena proses artikulasi yang saling berdekatan antara huruf $\tau$ dan $\varepsilon$ dengan $\dot{\tau}, \infty, \triangleleft$ dan $\dot{\varepsilon}$. Yang mana bunyi huruf $\tau$ dan $\varepsilon$ dihasilkan dengan cara mendekatkan akar lidah kepada dinding rongga kerongkongan tetapi tidak sampai menyentuhnya. Sedangkan bunyi huruf \& dan sdihasilkan dengan cara merapatkan kedua pita suara sehinga udara dari paru-paru yang melewati antara akar lidah dan dinding belakang rongga kerongkongan terhambat. Adapun bunyi huruf $\dot{\tau}$ dan $\dot{\varepsilon}$ dihasilkan dengan cara menempelkan belakang lidah pada langitlangit lunak. Hal ini menyebabkan para siswa belum bisa membedakan bunyi huruf-huruf tersebut sehingga mereka lebih cenderung untuk melafalkan huruf $\tau$ menjadi ه dan $\dot{\tau}$, huruf $\varepsilon$ menjadi \&, s, dan $\dot{\xi}$ karena huruf-huruf tersebut memiliki bunyi yang hampir sama/mirip sehingga lebih mudah untuk dilafalkan.

\section{Bunyi Frikatif}

\section{Perubahan bunyi huruf / / / / / menjadi / / /}

Perubahan bunyi huruf / $/ \mathbf{L} /$ / menjadi / / terjadi karena / dalam bahasa Indonesia dilambangkan dengan huruf /dz/, dan / ל/ dilambangkan dengan huruf /zh/, sedangkan / $/$ dilambangkan dengan huruf /z/. huruf /z/ lebih sering dijumpai dalam kata bahasa Indonesia sehingga lebih mudah dilafalkan dari pada huruf /dzal/, dan /zho\% /. Hal tersebut juga disebabkan oleh letak artikulasi yang berdekatan yaitu $/$ / dan / berada di bagian atas dari ujung lidah yang bertemu dengan dua buah gigi seri (ujung gigi depan yang atas), 
sedangkan /j/ berada di antara ujung lidah dengan dua buah gigi seri (gigi atas dan bawah) tetapi lebih dekat ke bawah. Hal ini menyebabkan para siswa lebih cenderung melafalkan huruf/ذ/dan/ $/$ menjadi/j/.

/ Perubahan bunyi huruf

Perubahan bunyi huruf / dalam bahasa Indonesia dilambangkan dengan huruf /ts/, dan dilambangkan dengan huruf /sh/ yakni bunyi tebal berat, begitu juga dengan / شang dilambangkan dengan huruf /sy/ dan bunyinya tebal berat. Sedangkan / / / dilambangkan dengan huruf /s/ yakni bunyi tipis ringan. Huruf /s/ lebih sering dijumpai dalam bahasa Indonesia sehingga lebih mudah dilafalkan dari pada /ts/, /sh/ dan /sy/. Hal tersebut juga disebabkan oleh letak artikulasi yang berdekatan yaitu / $/$ berada di bagian atas antara ujung lidah bertemu dengan dua buah gigi seri ( ujung gigi depan yang atas), dan ص/ berada di antara ujung lidah dengan ujung dua buah gigi seri (gigi atas dan bawah) tetapi lebih dekat ke bawah, adapun / / berada di bagian tengah antara lidah dengan langit-langit. Sedangkan $/ \omega$ / berada di antara ujung lidah dengan ujung dua buah gigi seri (gigi atas dan bawah) tetapi lebih dekat ke bawah. Hal ini menyebabkan para siswa lebih cenderung melafalkan huruf / menjadi /ش/, /ص/, / /

\section{Perubahan bunyi huruf / $/ 2$ menjadi / / /}

Perubahan bunyi huruf / $/$ / menjadi /o/ terjadi karena pengaruh kebiasaan dari bahasa pertama (ibu) yaitu bahasa daerah maupun bahasa Indonesia. Huruf / $/$ / dalam bahasa Indonesia dilambangkan dengan bunyi / ha/, sedangkan huruf / ه/ dilambangkan dengan huruf /h/ akan tetapi huruf /h/ lebih sering dijumpai dalam bahasa dareah maupun bahasa Indonesia sehingga lebih mudah dilafalkan dari pada huruf /h /.Hal tersebut juga disebabkan oleh letak artikulasi yang berdekatan yaitu/ //berada di tenggorokan bagian tengah, sedangkan / / / berada di tenggorokan bagian dalam (pangkal tenggorokan). Hal ini menyebabkan para siswa lebih cenderung melafalkan huruf /ح/menjadi / / /.

\section{Perubahan bunyi huruf $/ \tau /$ menjadi $/ \dot{\tau} /$}

Perubahan bunyi huruf $/ \tau /$ menjadi $/ \tau /$ terjadi karena adanya kemiripan antara bunyi huruf $/ \tau /$ dengan $/ \tau /$. Huruf $/ \tau /$ dalam bahasa Indonesia dilambangkan dengan bunyi $/ \mathrm{ha} /$, sedangkan huruf $/ \dot{\tau} /$ dilambangkan dengan huruf $/ \mathrm{kh} /$. Akan tetapi kedua huruf tersebut sering dijumpai dalam bahasa dareah maupun bahasa Indonesia sehingga sulit bagi siswa untuk membedakan bunyi kedua huruf tersebut dan huruf / kh/ lebih mudah dilafalkan dari pada 
bunyi huruf /ha/. Hal tersebut juga disebabkan oleh letak artikulasi yang berdekatan yaitu $/ \tau /$ berada di bagian tenggorokan tengah, sedangkan $/ \dot{\tau} /$ berada di ujung tenggorokan. Sehingga hal ini menyebabkan para siswa lebih cenderung

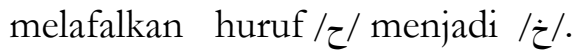

\section{Perubahan bunyi huruf $/ \dot{\tau} /$ menjadi / / /}

Perubahan bunyi huruf $/ \dot{\tau} /$ menjadi /o/ terjadi karena pengaruh kebiasaan dari bahasa pertama (ibu). Huruf $/ \dot{\tau} /$ dalam bahasa Indonesia dilambangkan dengan huruf $/ \mathrm{kh} /$, sedangkan huruf /s/ dilambangkan dengan huruf $/ \mathrm{h} /$ akan tetapi huruf $/ \mathrm{h} /$ lebih sering dijumpai dalam bahasa dareah maupun bahasa Indonesia sehingga lebih mudah dilafalkan dari pada bunyi huruf $/ \mathrm{kho} /$.Hal tersebut juga disebabkan oleh letak artikulasi yang berdekatan yaitu / $\dot{\tau} /$ berada di ujung tenggorokan, sedangkan / / / berada di tenggorokan bagian dalam (pangkal tenggorokan). Hal ini menyebabkan para siswa lebih cenderung melafalkan huruf $/ \dot{\tau} /$ menjadi / $/$.

\section{Perubahan bunyi huruf $/ \dot{\tau} /$ menjadi $/ \dot{\varepsilon} /$}

Perubahan bunyi huruf $/ \dot{\tau} /$ menjadi $/ \varepsilon /$ terjadi karena adanya kemiripan antara bunyi huruf $/ \dot{\tau} /$ dengan $/ \dot{\xi} /$. Huruf $/ \dot{\tau} /$ dalam bahasa Indonesia dilambangkan dengan huruf $/ \mathrm{kh} /$, sedangkan huruf $/ \dot{\varepsilon} /$ dilambangkan dengan huruf /g atau gh/, karena kedua huruf tersebut lebih sering dijumpai dalam bahasa Indonesia sehingga sulit bagi siswa untuk membedakan bunyinya dan lebih mudah melafalkan huruf $/ \mathrm{g} /$ dari pada huruf $/ \mathrm{kh} /$. Hal tersebut juga disebabkan oleh letak artikulasi yang sama yaitu berada di bagian ujung tenggorokan, dimana kedua bunyi itu dihasilkan dengan cara menempelkan belakang lidah pada langit-langit lunak. Hal ini menyebabkan para siswa lebih cenderung melafalkan huruf $/ \dot{\tau} /$ menjadi $/ \dot{\xi} /$.

\section{Perubahan bunyi huruf/ $/ \dot{\varepsilon}$ menjadi $/ \dot{\tau} /$}

Perubahan bunyi huruf $/ \xi /$ menjadi $/ \tau /$ terjadi karena adanya kemiripan antara bunyi huruf $/ \dot{\xi} /$ dengan $/ \tau /$. Huruf $/ \dot{\xi} /$ dalam bahasa Indonesia dilambangkan dengan huruf /g atau gh/, sedangkan huruf / $خ /$ dilambangkan dengan $/ \mathrm{kh} /$. Selain itu huruf $/ \mathrm{g} / \mathrm{dan} / \mathrm{kh} /$ lebih sering dijumpai dalam bahasa Indonesia, hal ini menyebabkan siswa MTs. Raudlatul Jannah sulit membedakannya sehingga lebih cenderung melafalkan huruf $/ \dot{\xi} /$ menjadi $/ \dot{\tau} /$. 


\section{Perubahan bunyi huruf/ $/ \varepsilon /$ menjadi / / /}

Perubahan bunyi huruf / $\dot{\xi} /$ menjadi / $/$ / terjadi karena huruf / $/$ / dalam bahasa Indonesia dilambangkan dengan bunyi /gh/, sedangkan huruf $/$ / / dilambangkan dengan huruf /h/, karena huruf /h/ lebih sering dijumpai dalam bahasa dareah maupun bahasa Indonesia sehingga lebih mudah dilafalkan dari pada huruf $/ \mathrm{h} /$. Hal tersebut juga disebabkan oleh letak artikulasi yang berdekatan yaitu / $/$ / berada di ujung tenggorokan, sedangkan / ه/ berada di tenggorokan bagian dalam (pangkal tenggorokan). Sehingga hal ini menyebabkan para siswa lebih cenderung melafalkan huruf $/ \dot{\varepsilon} /$ menjadi $/$ s/.

\section{/ض / Perubahan bunyi huruf / ל / menjadi}

Perubahan bunyi huruf / /ط/ menjadi / terjadi karena huruf dalam bahasa Indonesia dilambangkan dengan huruf /zh/ yakni bunyi tebal, sedangkan huruf /ض/ dilambangkan dengan huruf /dh/ yakni bunyi sedikit ringan, karena huruf / dh/ lebih sedikit ringan untuk dilafalkan sehingga huruf /dh/ lebih mudah dilafalkan dari pada huruf / zh/.Hal tersebut juga disebabkan oleh letak artikulasi yang berdekatan yaitu $/$ / berada di ujung lidah yang bertemu ujung gigi depan yang atas, sedangkan / ض/ berada di sisi lidah yang bertemu geraham atas. Sehingga hal ini menyebabkan para siswa lebih cenderung melafalkan huruf/ظ/menjadi ض/.

\section{Perubahan bunyi huruf / ל/ menjadi /}

Perubahan bunyi huruf / ל / $/$ / menjadi terjadi karena adanya kemiripan bunyi antara huruf / ל/ dengan / ל/ Huruf / b/ dalam bahasa Indonesia dilambangkan dengan huruf /zh/, sedangkan huruf / ذ/ dilambangkan dengan huruf /dz/, karena /dz/ lebih sering dijumpai dalam suatu kalimat berbahasa Arab sehingga siswa sulit membedakan bunyi antara huruf /zh/ dengan /dz/ dan huruf /dz/ lebih mudah dilafalkan dari pada huruf /zh/.Hal tersebut juga disebabkan oleh letak artikulasi yang sama yaitu huruf / / dan / ذ/ berada di bagian ujung lidah yang bertemu dengan ujung gigi depan yang atas, dimana bunyi itu dihasilkan dengan cara meletakkan ujung lidah antara gigi bawah dan atas, tanpa menutup arus udara secara sempurna . Hal ini menyebabkan para siswa lebih cenderung melafalkan huruf / ל / menjadi $/ \mathrm{s} /$.

\section{Perubahan bunyi huruf / ל/ menjadi / /}

Perubahan bunyi huruf / ל / menjadi/د/ terjadi karena huruf/ל/dalam bahasa Indonesia dilambangkan dengan bunyi /zh/, sedangkan huruf / / / 
dilambangkan dengan huruf /d/. Akan tetapi huruf /d/ lebih sering dijumpai dalam bahasa Indonesia sehingga lebih mudah dilafalkan dari pada huruf /zh/.Hal tersebut juga disebabkan oleh letak artikulasi yang berdekatan yaitu / $/$ / berada di bagian ujung lidah yang bertemu dengan ujung gigi depan yang atas, sedangkan / / / berada di bagian ujung lidah yang bertemu dengan gusi atas. Hal ini menyebabkan para siswa lebih cenderung melafalkan huruf / ל / menjadi $/ \mathrm{s} /$.

\section{Perubahan bunyi huruf /}

Perubahan bunyi huruf / $/$ menjadi / T/ terjadi karena huruf / dalam bahasa Indonesia dilambangkan dengan bunyi /zh/, sedangkan huruf $/$ f dilambangkan dengan huruf $/ \mathrm{J} /$. Akan tetapi huruf /J/ lebih sering dijumpai dalam bahasa Indonesia sehingga lebih ringan dan mudah dilafalkan dari pada huruf /zh/.Hal tersebut juga disebabkan oleh letak artikulasi yang berdekatan yaitu $/$ / berada di bagian ujung lidah yang bertemu dengan ujung gigi depan yang atas, sedangkan $/$ / berada di antara tengah lidah dengan langit-langit. Hal ini menyebabkan para siswa lebih cenderung melafalkan huruf / ל/ menjadi ج/.

\section{/ض/ Merubahan bunyi huruf}

Perubahan bunyi huruf ص/ / menjadi terjadi karena adanya kemiripan antara huruf /ص/ dengan /ص/ص/, dimana huruf /ص/ض/Sam bahasa Indonesia dilambangkan dengan huruf /sh/ yang menghasilkan bunyi melalui sentuhan ujung lidah kepada gusi sehingga menyebabkan penyempitan keluarnya udara yang kemudian keluar secara pelan-pelan tanpa letupan, sedangkan huruf /ض/ dilambangkan dengan /dh/ yang menghasilkan bunyi melalui sentuhan ujung lidah kepada pangkal gigi atas depan gusi (geraham atas). Selain itu huruf /sh/ lebih sering dijumpai dalam bahasa Indonesia maupun bahasa Arab, namun pada kenyataannya siswa belum bisa membedakannya sehingga lebih cenderung melafalkan huruf ص/ menjadi / /

\section{Perubahan bunyi huruf / $/$ menjadi /}

Perubahan bunyi huruf / $/ \mathrm{j}$ menjadi / terjadi karena pengaruh kebiasaan dari bahasa pertama (ibu) yaitu bahasa daerah, dimana huruf / j/ dalam bahasa Indonesia dilambangkan dengan bunyi /z/ yakni bunyi tebal berat, sedangkan huruf ج/ dilambangkan dengan huruf /j/ yakni bunyi tipis ringan. selain itu, kedua huruf tersebut lebih sering dijumpai dalam bahasa Indonesia, akan tetapi para siswa masih sulit membedakan bunyi kedua huruf 
tersebut sehingga huruf / $\mathrm{z} /$ lebih mudah dan ringan dilafalkan menggunakan huruf $/ \mathrm{j} /$. Hal tersebut juga disebabkan oleh letak artikulasi yang berdekatan yaitu / $/$ / berada di ujung lidah diantara gigi atas dan bawah (lebih dekat ke bawah), sedangkan / / berada di bagian tengah lidah dengan cara daun lidah menekan langit-langit keras. Hal ini menyebabkan para siswa lebih cenderung melafalkan huruf / $/$ menjadi / $/$.

\section{Perubahan bunyi huruf $/ \varepsilon /$ menjadi $/ \_/$}

Perubahan bunyi huruf $/ \varepsilon /$ menjadi / / / terjadi karena pengaruh kebiasaan dari bahasa pertama (ibu) serta kemiripan antara bunyi huruf $/ \varepsilon /$ dan $/ \& /$, dimana huruf $/ \varepsilon /$ dalam bahasa Indonesia dilambangkan dengan bunyi /'a/, sedangkan huruf / $/$ / dilambangkan dengan huruf /a/, namun huruf /a/ lebih sering dijumpai dalam bahasa dareah maupun bahasa Indonesia sehingga lebih mudah dilafalkan dari pada huruf /'a/.Hal tersebut juga disebabkan oleh letak artikulasi yang berdekatan yaitu / $/$ / berada di tenggorokan bagian tengah, sedangkan $/ \varsigma /$ berada di tenggorokan bagian dalam (pangkal tenggorokan). Hal ini menyebabkan para siswa lebih cenderung melafalkan huruf $/ \varepsilon /$ menjadi $/ s /$.

\section{Perubahan bunyi huruf / $/$ / menjadi / $/$}

Perubahan bunyi huruf / $/$ / menjadi / $/$ terjadi karena huruf / $/$ / dalam bahasa Indonesia dilambangkan dengan bunyi /'a/, sedangkan huruf /ه/ dilambangkan dengan huruf /h/, karena huruf /h/ lebih sering dijumpai dalam bahasa Indonesia sehingga lebih mudah dilafalkan dari pada huruf /'a/.Hal tersebut juga disebabkan oleh letak artikulasi yang berdekatan yaitu $/ \varepsilon /$ berada di tenggorokan bagian tengah, sedangkan / / / berada di tenggorokan bagian dalam (pangkal tenggorokan). Sehingga hal ini menyebabkan para siswa lebih cenderung melafalkan huruf $/ \varepsilon /$ menjadi / $/$ /.

\section{Perubahan bunyi huruf $/ \varepsilon /$ menjadi / $/$}

Perubahan bunyi huruf $/ \varepsilon /$ menjadi $/ \dot{\varepsilon} /$ terjadi adanya kemiripan antara huruf $/ \varepsilon /$ dan $/ \varepsilon /$, dimana huruf $/ \varepsilon /$ dalam bahasa Indonesia dilambangkan dengan bunyi /'a/, sedangkan huruf / $\dot{\xi} /$ dilambangkan dengan huruf /g/ atau /gh/. Selain itu kedua huruf tersebut lebih sering dijumpai dalam suatu kalimat berbahasa Arab namun jarang dijumpai dalam bahasa Indonesia, sehngga beberapa siswa belum mampu membedakanya dan huruf /'a/ dilafalkan menggunakan huruf /gh/.Hal tersebut juga disebabkan oleh letak artikulasi yang berdekatan yaitu $/ \varepsilon /$ berada di tenggorokan bagian tengah, sedangkan $/ \dot{\varepsilon} /$ 
berada di ujung tenggorokan. Hal ini menyebabkan para siswa lebih cenderung melafalkan huruf / $/ \varepsilon /$ menjadi $/ \dot{\varepsilon} /$.

\section{Perubahan bunyi huruf $/$ / menjadi / /}

Perubahan bunyi huruf $/ \mathrm{J} /$ menjadi / $/ \mathrm{s}$ terjadi karena adanya kemiripan antara huruf huruf $/ \mathrm{j} /$ dengan $/ \mathrm{s} /$ serta pengaruh kebiasaan dari bahasa pertama (ibu). Selain itu / ذ/ dalam bahasa Indonesia dilambangkan dengan bunyi /dz/, sedangkan huruf / / / dilambangkan dengan huruf /d/, akan tetapi huruf /d/ lebih sering dijumpai dalam bahasa bahasa Indonesia dan lebih mudah dilafalkan dari pada huruf /dz/.Hal tersebut juga disebabkan oleh letak artikulasi yang berdekatan yaitu / $/$ / berada di bagian ujung lidah yang bertemu dengan ujung gigi depan yang atas, sedangkan / / / berada di ujung lidah yang bertemu dengan gusi atas. Hal ini menyebabkan para siswa lebih cenderung melafalkan huruf / ذ/ menjadi / د/.

\section{Letupan/Hambat}

\section{/ Perubahan bunyi huruf / / menjadi /}

Perubahan bunyi huruf / / menjadi / / terjadi karena / dalam bahasa Indonesia dilambangkan dengan /q/ yakni huruf tebal berat, sedangkan huruf / ك/ dilambangkan dengan huruf /k/ yakni huruf tipis ringan, karena huruf $/ \mathrm{k} /$ lebih sering dijumpai dalam bahasa Indonesia dan lebih mudah dilafalkan dari pada huruf $/ \mathrm{q} /$. Hal tersebut juga disebabkan oleh letak artikulasi yang berdekatan yaitu / $/$ / berada di pangkal lidah (paling belakang) dekat dengan anak lidah dengan langit-langit yang lurus di atasnya, sedangkan / berada di pangkal lidah tepatnya sebelah bawah (sedikit ke depan) bertemu dengan langit-langit bagian atas. Selain itu / / dan / merupakan bunyi letupan. Sehingga hal ini menyebabkan para siswa lebih cenderung melafalkan huruf/ق/menjadi /

\section{/ق/ Perubahan bunyi huruf /}

Perubahan bunyi huruf / / menjadi / / t terjadi karena adanya

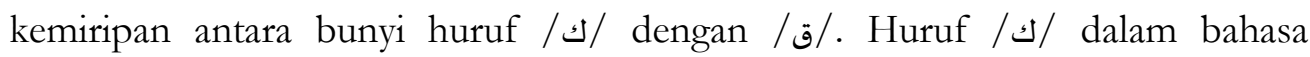
Indonesia dilambangkan dengan huruf / k/, sedangkan huruf / / / dilambangkan dengan /q/. Selain itu huruf /k/ dan /q/ lebih sering dijumpai dalam bahasa Indonesia, hal ini menyebabkan siswa MTs. Raudlatul Jannah sulit membedakannya sehingga lebih cenderung melafalkan huruf / كenjadi / / 


\section{Perubahan bunyi huruf / $/$ / menjadi / /}

Perubahan bunyi huruf /b/ menjadi / / t terjadi karena adanya kemiripan antara bunyi huruf $/ \mathrm{b} /$ dengan $/ ت /$. Selain itu huruf $/ \mathrm{b} /$ dalam bahasa Indonesia dilambangkan dengan huruf /th/, sedangkan huruf / / / dilambangkan dengan huruf /t/. Namun huruf / $\mathrm{t} /$ lebih sering dijumpai dalam bahasa Indonesia sehingga lebih mudah dilafalkan dari pada huruf /th/.Hal tersebut juga disebabkan oleh letak artikulasi yang sama yaitu huruf / $\mathrm{b} /$ dan / / berada di bagian ujung lidah dengan bertemu pada gusi atas. hal ini menyebabkan para siswa lebih cenderung melafalkan / b/ menjadi /ت/.

\section{/ض/ Perubahan bunyi huruf / ط}

Perubahan bunyi huruf / / / menjadi / / / / terjadi karena huruf dalam bahasa Indonesia dilambangkan dengan huruf /th/, sedangkan huruf / / dilambangkan dengan huruf /dh/. karena kedua huruf tersebut jarang dijumpai dalam bahasa Indonesia sehingga siswa belum bisa membedakannya dan juga melafalkan huruf /th/ menggunakan / dh/.Hal tersebut juga disebabkan oleh letak artikulasi yang berdekatan yaitu / b/ berada di ujung lidah dengan bertemu gusi atas, sedangkan /ض/ berada di sisi lidah dengan bertemu geraham atas. Hal ini menyebabkan para siswa lebih cenderung melafalkan huruf /b/ menjadi /ض/.

\section{Perubahan bunyi huruf /ض/menjadi / /}

Perubahan bunyi huruf /ض/ menjadi / / / terjadi karena adanya

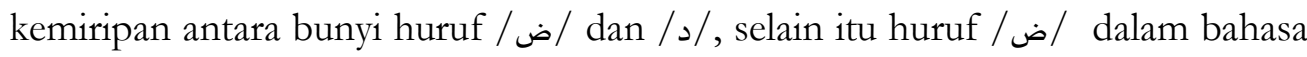
Indonesia dilambangkan dengan bunyi /dh/, sedangkan huruf / / / dilambangkan dengan huruf /d/, karena huruf /d/ lebih sering dijumpai dalam bahasa Indonesia sehingga lebih mudah dilafalkan dari pada huruf /dh/.Hal tersebut juga disebabkan oleh letak artikulasi yang berdekatan yaitu ض/ berada di sisi lidah bertemu dengan geraham atas, sedangkan / / / berada di ujung lidah bertemu dengan gusi atas. Hal ini menyebabkan para siswa lebih cenderung melafalkan huruf/ض/menjadi / / /.

\section{Penutup}

Kegiatan pengkajian terhadap ketidaksesuaian antara realita dan semestinya, yang terjadi pada lingkup kebahasaan sebagai proses kerja analisis kesalahan adalah sangat penting untuk menemukan segala penyimpangan yang terjadi sehingga mampu menemukan aspek kesalahan beserta solusi dalam 
mewujudkan keberhasilan pembelajaran bahasa. Hasil penelitian ini menunjukkan bahwa bentuk-bentuk kesalahan fonologi yang sering terjadi pada saat kegiatan membaca teks berbahasa Arab yaitu kesalahan pada bunyi yang ditinjau dari aspek faktor artikulasinya diantaranya ada pada ; 1) bunyi apicodental-alveolar seperti huruf bdan ض. 2) Bunyi inter-dental seperti huruf ث, ذ, dan ظ. 3) Bunyi foronto-palatal seperti huruf ش. 4) Bunyi dorso-uvular seperti huruf ق. 5) Bunyi dorso-velar seperti huruf dan j. 7) Bunyi root-pharyngeals seperti huruf $\varepsilon$ dan $\tau$. Adapun kesalahan bunyi yang ditinjau dari aspek cara artikulasinya yaitu ada pada: 1) bunyi frikatif, seperti

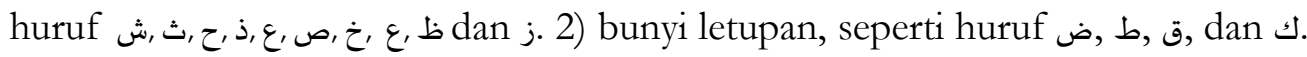
Penelitian ini bermanfaat bagi para pembelajar bahasa asing (Arab) dalam mengantisipasi terjadi kesalahan serupa. Oleh karena itu, kajian analisis kesalahan fonologis ini masih perlu dilakukan pengembangan pengkajian berikutnya yang lebih mendalam.

\section{Bibliografi}

Akhmad Dzukaul Fuad. "Keunikan Fonologi Bahasa Arab Etnis Migran Di Nusantara (Studi Kasus Pada Kampung Arab Pamekasan Madura)," n.d.

Amrulloh, Muhammad Afif. "Kesamaan Bunyi Pada Sajak (Kajian Fonologi AlQur'an Dalam Surat Al 'Asar).” Jurnal Al Bayan 9, no. 1 (2017).

Batmang, Batmang. "Kesalahan Fonologis Dalam Berbicara Bahasa Arab Pada Mahasiswa Matrikulasi Stain Kendari." Al-Izæah 8, no. 1 (2013).

Eric Kunto Aribowo. "Fonologi Dan Ortogtrafi Bahasa Arab." Seminar Nasional Bulan Babasa Dan Sastra, 2013, 202-2011.

Fitria Lathifah, Syihabuddin Syihabuddin, M. Zaka Al Farisi. "Analisis Kesalahan Fonologis Dalam Keterampilan Membaca Teks Bahasa Arab.” Arabiyat: Jurnal Pendidikan Bahasa Arab Dan Kebahasaaraban 4, no. 2 (2017).

Lubis, Nur Janah. "Tahlil al-Akhtha' al-Shauthiyah (Dirasah Fi Ilm Wazhaif alAshwat) Fi Qira'ah al-Nash al-'Arabiyah Bi al-Shaf al-Sabi' Fi al-Madrasah al-Mutawasithah al-Islamiyah al-Mu'allimin al-Jami’ah al-Washliyah Medan." UIN Sumatera Utara, 2018.

M.Tontowi. "Fonologi Dalam Pendidikan Dan Pelatihan Bahasa Arab Guru Mi Tingkat Dasar Pada Diklat Keagamaan Kota Palembang," n.d.,

Mohd Azidan Abdul Jabbar. "Gangguan Bunyi Melayu Dalam Sebutan Arab: Satu Analisis Ringkas." Pertanika Journal Social, Science and Humanities 12, no. 2 (2004): 101-10.

Mufarodi. "Fonologi Dan Morfologi Bahasa Arab 'Âmiyah Mesir." Arabiyat 2, no. 2 (2015): 192-215.

Suprianti, Wiwik. "Analisis Kesalahan Pelafalan Bunyi Bahasa Prancis Siswa Kelas XI SMA Negeri 2 Sleman.” Universitas Negeri Yogyakarta, 2012. 